\title{
Induction of Cell Division in a Temperature-sensitive Division Mutant of Escherichia coli by Inhibition of
} Protein Synthesis

\author{
By M. A. DE PEDRO AND J. L. CÁNOVAS \\ Instituto de Biología Celular, C.S.I.C., Velázquez I44, Madrid-6, Spain
}

(Received 2 August 1976; revised 24 October 1976)

\begin{abstract}
SUMMARY
Synchronous cells of the thermosensitive division-defective Escherichia coli strain MACI $(\operatorname{div} A)$ divided at the restrictive temperature $\left(42^{\circ} \mathrm{C}\right)$ if they were allowed to grow at $42{ }^{\circ} \mathrm{C}$ for a certain period before protein synthesis was inhibited by adding chloramphenicol (CAP) or rifampicin. The completion of chromosome replication was not required for such $\operatorname{div} A$-independent division. Synchronous cells of strain MACI divided in the presence of an inhibitor of DNA synthesis, nalidixic acid, if they were shifted to $42^{\circ} \mathrm{C}$ and CAP or rifampicin was added after some time; cells of the parent strain MC6 $\left(\operatorname{div} A^{+}\right)$treated in the same way did not divide. These data suggest that coupling of cell division to DNA synthesis depends on the $\operatorname{div} A$ function. The ability to divide at $42{ }^{\circ} \mathrm{C}$, whether or not chromosome termination was allowed, was directly proportional to the mean cell volume of cultures at the time of CAP addition, suggesting that cells have to be a certain size to divide under these conditions. The period of growth required for CAP-induced division had to be at the restrictive temperature; when cells were grown at $30^{\circ} \mathrm{C}$, in the presence of nalidixic acid to prevent normal division, they did not divide on subsequent transfer to $42^{\circ} \mathrm{C}$ followed, after a period, by protein synthesis inhibition. A model is proposed in which the role of $\operatorname{div} A$ as a septation initiator gene is to differentiate surface growth sites by converting a primary unregulated structure, with the capacity to make both peripheral wall and septum, to a secondary structure committed to septum formation.
\end{abstract}

\section{INTRODUCTION}

Cell growth and cell division are coordinated processes which are linked in Escherichia coli by chromosome replication. Initiation of chromosome replication occurs when the ratio of cell mass (or volume) to the number of chromosome origins reaches a value which is constant over a wide range of growth conditions (Donachie, 1968; Pritchard, 1968). Cell division follows after an interval which encompasses the time (C) for replication and the time (D) between the end of replication and physical cell separation (Cooper \& Helmstetter, I968). The values of $C$ and $D$ are constant at different growth rates ( $I$ to 3 generations $\mathrm{h}^{-1}$; Cooper \& Helmstetter, I968; Helmstetter \& Pierucci, 1976). In E. coli KI 2, C is also constant in slow-growing cells (less than I generation $\mathrm{h}^{-1}$; Chandler, Bird \& Caro, 1975). Under normal conditions, completion of chromosome replication is a prerequisite for division (Clark, I968; Helmstetter \& Pierucci, 1968). The coupling between DNA replication and cell division is still poorly understood and the nature of the timing control systems for the division processes that take place during the $\mathrm{D}$ period is unknown (Donachie, Jones \& Teather, 1973). Another unexplained observation is that, for doubling times between 27 and $45 \mathrm{~min}$, a fixed period of protein synthesis which normally occurs concurrent with 
chromosome replication but can be uncoupled from it, is required for division (Pierucci \& Helmstetter, 1969). Previous work (Pedro, Llamas \& Cánovas, 1975) on a thermosensitive division-defective strain of $E$. coli, MACI, showed that the gene (divA) mutated in this organısm appears to control cell division during a period which lasts $40 \mathrm{~min}$ and ends $20 \mathrm{~min}$ before division, a period concurrent with DNA replication, and that its function can be uncoupled from replication. The same work also supports the view that $\operatorname{div} A$ is involved in the initiation of the division processes which usually take place during the $\mathrm{D}$ period. Finally, it has been proposed that $\operatorname{div} A$ has a role in fixing the time for the protein synthesis period necessary for division in $E$. coli. This paper shows that when the $\operatorname{div} A$ function is impaired, cell division can be carried out under certain conditions. The completion of a round of DNA replication is not a prerequisite for this $\operatorname{div} A$-independent cell division.

\section{METHODS}

The isolation and properties of the Escherichia coli mutant MACI, a thermosensitive, division-defective, str- $r$ derivative of $E$. coli $\mathrm{K}_{2} 2 \mathrm{~F}-$ thy A dra drm thi thr leu pro (MC6), have been described previously (Pedro et al., 1975). Synchronous cultures growing at $30^{\circ} \mathrm{C}$ on LB medium (generation time $\tau$ approx. $50 \mathrm{~min}$ ) were used. The materials and methods used to obtain these cultures by the membrane elution technique and the methods employed for cell number determinations and for temperature shifts from 30 to $42{ }^{\circ} \mathrm{C}$, and vice versa, have also been described (Pedro et al., 1975). To calculate the mean cell volume of cultures, the cell volume distribution was determined by serial counting of the particles between two size thresholds, using a model ZBI Coulter counter. Each lower threshold was set at the same size as the preceding upper threshold.

\section{RESULTS}

\section{Division of strain MACI cells at $42{ }^{\circ} \mathrm{C}$ in the presence of protein synthesis inhibitors}

The experiments described in this paper arose from an unexpected observation illustrated in Fig. I (a). To test whether the product of the gene mutated in strain MACI could revert to the active form after heat treatment, a synchronous culture was given a long heat shock at $42{ }^{\circ} \mathrm{C}$, starting when the cells were close to becoming heat resistant (20 min after cell elution). The culture was then incubated at $30^{\circ} \mathrm{C}$ and chloramphenicol (CAP) was added. Protein synthesis stopped in about $2 \mathrm{~min}$. Cell division occurred under these conditions but it had different characteristics from the control culture to which no CAP had been added (Fig. I). Division began after $20 \mathrm{~min}$ with CAP compared with $50 \mathrm{~min}$ in the control, and the number of particles in the presence of CAP more than doubled, whereas only 60 to $70 \%$ of the control cells were able to divide as observed previously (Pedro et al., 1975). These results suggested that the protein synthesis-independent division of strain MACI might not depend on the $\operatorname{div} A$ product. This appears to be true because cells divided in the presence of CAP even at $42^{\circ} \mathrm{C}$ (Fig. I $b$ ). Division at the restrictive temperature required both CAP and an incubation period at $42^{\circ} \mathrm{C}$ before antibiotic addition; cells without CAP or cells to which CAP was added after only $10 \mathrm{~min}$ at $42{ }^{\circ} \mathrm{C}$ did not divide. When the experiments illustrated in Fig. I were repeated using rifampicin $\left(400 \mu \mathrm{g} \mathrm{ml}^{-1}\right)$ instead of CAP, similar results were obtained.

The ability to divide at $42{ }^{\circ} \mathrm{C}$ in the presence of CAP was directly proportional to the length of the previous incubation period without the protein synthesis inhibitor (Fig. $2 a$ ). A certain period of incubation after cell elution was necessary before the CAP was added 
(a)

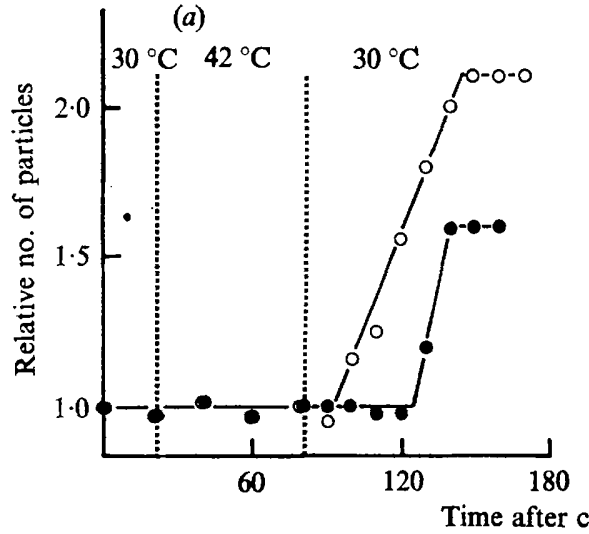

(b)

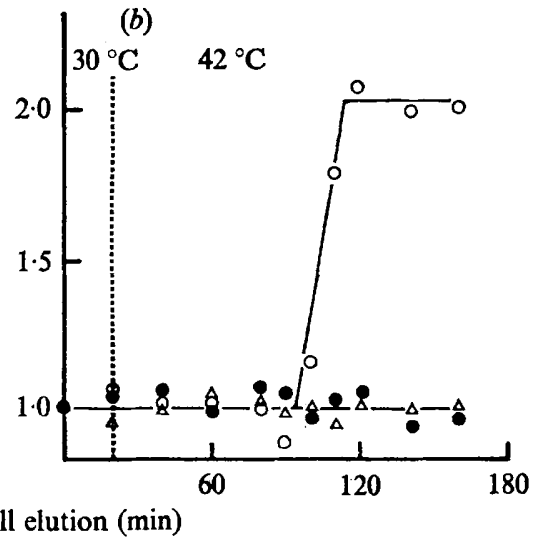

Fig. I. Division of strain MACI at $30^{\circ} \mathrm{C}$ and $42{ }^{\circ} \mathrm{C}$ in the presence of CAP. (a) A synchronous culture growing at $30^{\circ} \mathrm{C}$ on LB medium was subjected to $60 \mathrm{~min}$ at $42{ }^{\circ} \mathrm{C}$ starting $20 \mathrm{~min}$ after cell elution. The culture was then returned to $30^{\circ} \mathrm{C}$ and divided into two parts: $\operatorname{CAP}\left(200 \mu \mathrm{g} \mathrm{ml}^{-1}\right)$ was immediately added to one part $(O)$ but not to the other $(O)$. Initial particle counts $\mathrm{ml}^{-1}$ were $5 \times 10^{5}$.

(b) A synchronous culture growing at $30^{\circ} \mathrm{C}$ on LB medium was shifted to $42^{\circ} \mathrm{C} 20$ min after cell elution; the culture was divided into two parts $60 \mathrm{~min}$ later and CAP $\left(200 \mu \mathrm{g} \mathrm{m}^{-1}\right)$ was added to one part (O) but not to the other (O). An identical culture was also shifted to $42{ }^{\circ} \mathrm{C} 20 \mathrm{~min}$ after cell elution and CAP $\left(200 \mu \mathrm{g} \mathrm{ml}^{-1}\right)$ was added $10 \mathrm{~min}$ later $(\triangle)$. Initial particle counts $\mathrm{ml}^{-1}$ were $5 \times 10^{5}(O, O)$ and $4 \times 10^{5}(\triangle)$.

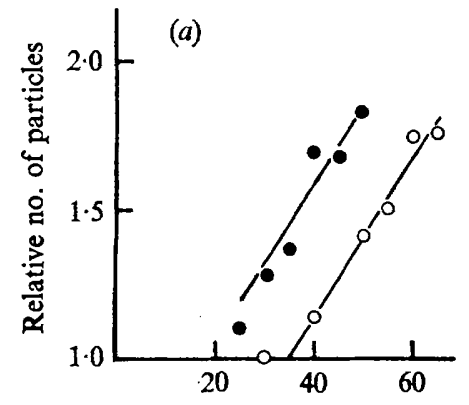

Time after cell elution when CAP was added (min)

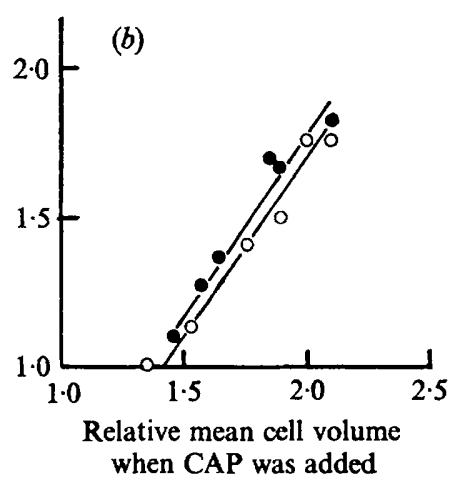

Fig. 2. Acquisition of ability to divide at $42^{\circ} \mathrm{C}$ in the presence of CAP in strain MACI. A number of synchronous cultures growing at $30^{\circ} \mathrm{C}$ on $\mathrm{LB}$ medium were shifted to $42{ }^{\circ} \mathrm{C}$ at the time of cell elution (O) or $20 \mathrm{~min}$ after $(\mathrm{O})$. CAP $\left(200 \mu \mathrm{g} \mathrm{ml}^{-1}\right)$ was added to these cultures at different times and the maximum number of particles in each culture was measured and plotted against $(a)$ the time of CAP addition or $(b)$ the mean cell volume of cultures at CAP addition. To calculate relative values, those corresponding to the mean cell volume and particle counts $\mathrm{ml}^{-1}$ at the time of cell elution were taken as $\mathbf{I} \cdot 0$.

to detect CAP-induced divisions; this was about $20 \mathrm{~min}$ in synchronous cultures shifted to $42{ }^{\circ} \mathrm{C}$ at elution and approximately $35 \mathrm{~min}$ in cultures shifted to $42{ }^{\circ} \mathrm{C} 20 \mathrm{~min}$ after elution (Fig. 2a). The ability to divide at $42{ }^{\circ} \mathrm{C}$ was also directly proportional to the mean cell volume measured in the cultures at the time of CAP addition (Fig. 2b). A critical volume, which was almost the same in cultures shifted to $42{ }^{\circ} \mathrm{C}$ at elution or $20 \mathrm{~min}$ later, was required before divisions were detected. Thus, cell growth to a critical size is necessary for CAP-induced division at $42{ }^{\circ} \mathrm{C}$. 


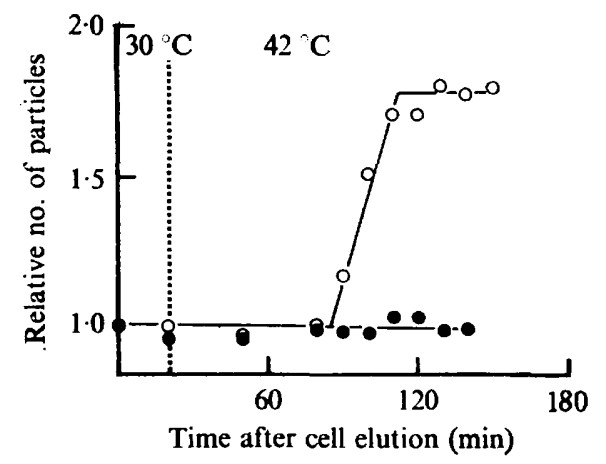

Fig. 3. Lack of inhibition by NA of strain MACI division at $42^{\circ} \mathrm{C}$. NA $\left(80 \mu \mathrm{g} \mathrm{m}^{-1}\right)$ was added at the time of cell etution to a synchronous culture growing at $30^{\circ} \mathrm{C}$ on LB medium and 20 min later the temperature was shifted to $42{ }^{\circ} \mathrm{C}$; the culture was divided into two parts after another $60 \mathrm{~min}$ and CAP (200 $\left.\mu \mathrm{g} \mathrm{ml}^{-1}\right)$ was added to one part $(O)$ but not to the other $(O)$. Initial particle counts $\mathrm{ml}^{-1}$ were $6 \times 10^{5}$.
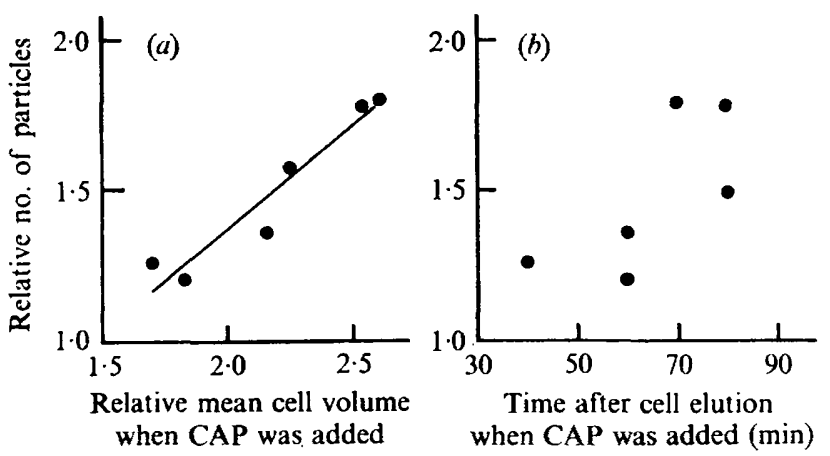

Fig. 4. Acquisition of ability to divide at $42{ }^{\circ} \mathrm{C}$ in the presence of NA in strain MACI. NA ( $\left.80 \mu \mathrm{g} \mathrm{ml}^{-1}\right)$ was added at the time of cell elution to a number of synchronous cultures growing at $30^{\circ} \mathrm{C}$ on $\mathrm{LB}$ medium and $20 \mathrm{~min}$ later the temperature was shifted to $42{ }^{\circ} \mathrm{C}$. CAP $\left(200 \mu \mathrm{g} \mathrm{ml}^{-1}\right)$ was added to these cultures at different times and the maximum number of particles in each culture was measured and plotted against $(a)$ the mean cell volume of cultures at CAP addition or $(b)$ the time of CAP addition. Relative values were calculated as in Fig. 2.

\section{Division of strain MACI cells at $42{ }^{\circ} \mathrm{C}$ in the presence of nalidixic acid}

Completion of chromosome replication is not a prerequisite for $\operatorname{div} A$-independent cell division. This was shown in synchronous cultures of strain MACI to which nalidixic acid (NA) was added at the time of cell elution. Cells did not divide when they were kept at $30^{\circ} \mathrm{C}$. However, if the temperature was shifted to $42{ }^{\circ} \mathrm{C}$ and CAP (or rifampicin) was added after some time, the number of cells increased (Fig. 3). No division was observed without the protein synthesis inhibitor. Cell growth at $42{ }^{\circ} \mathrm{C}$ in the presence of NA was variable; the mean cell volume under these conditions after a fixed incubation period was different in different cultures. Nevertheless, the ability to divide at $42{ }^{\circ} \mathrm{C}$ in the presence of NA was proportional to the mean cell volume at the time of CAP addition (Fig. $4 a$ ), but not to the length of the incubation period before adding the protein synthesis inhibitor (Fig. $4 b$ ). Division without completion of chromosome replication was only possible when the $\operatorname{div} A$ product was inactivated; cell division in the presence of NA was not observed in synchronous cultures of strain MACI growing at $30^{\circ} \mathrm{C}$ or of the parent strain MC6 growing at $42{ }^{\circ} \mathrm{C}$, even 


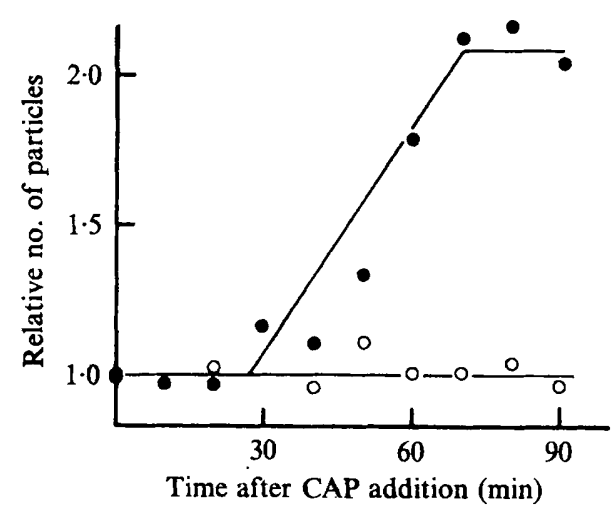

Fig. 5. Lack of CAP-induced division of strain MACI at $42^{\circ} \mathrm{C}$ caused by prolonged previous incubation at $30^{\circ} \mathrm{C}$. A synchronous culture growing on LB medium at $30^{\circ} \mathrm{C}$, to which NA $(80 \mu \mathrm{g}$ $\mathrm{ml}^{-1}$ ) had been added at the time of cell elution, was divided into two parts $20 \mathrm{~min}$ after elution. One part was immediately shifted to $42{ }^{\circ} \mathrm{C}(O)$ and the other was shifted 40 min later (O). CAP $\left(200 \mu \mathrm{g} \mathrm{ml}^{-1}\right)$ was added to both parts $60 \mathrm{~min}$ after their corresponding temperature change. Initial particle counts $\mathrm{ml}^{-1}$ were $2.8 \times 10^{5}$.

if CAP (or rifampicin) was added when the mean cell volume was rather large (data not shown).

Previous studies on strain MACI behaviour (Pedro et al., 1975) suggested that division is controlled by the $\operatorname{divA}$ gene for a period (PA) of about $40 \mathrm{~min}$ starting 55 to $60 \mathrm{~min}$ before physical cell separation. If this is true, PA for the first division round ends $30 \mathrm{~min}$ after the elution of synchronous cultures ( $\tau$ approx. $50 \mathrm{~min}$ ) and PA for the second division round must start $40 \mathrm{~min}$ after elution. In the experiments reported above, the temperature shift-up was probably carried out before both the end of the first PA and the beginning of the second PA. The experiment illustrated in Fig. 5 was designed to test if strain MACI could divide in the presence of NA when the temperature shift-up was carried out after the theoretical initiation of PA for the second division round. A synchronous culture to which NA was added at elution, was shifted to $42{ }^{\circ} \mathrm{C}$ about one generation time later and CAP was added after another $60 \mathrm{~min}$. No division was observed in this culture in contrast to a parallel control culture shifted to $42{ }^{\circ} \mathrm{C} 20 \mathrm{~min}$ after elution (Fig. 5).

\section{DISCUSSION}

Apparently, the control of septation by the $\operatorname{divA}$ gene can be by-passed in strain MACI cells if they are allowed to reach a critical size at the restrictive temperature before protein synthesis is inhibited. The $\operatorname{div} A$-independent division process cannot be blocked by inhibition of DNA synthesis which suggests that coupling of cell division to chromosome replication depends on the $\operatorname{div} A$ function.

Induction of $E$. coli cell division by protein synthesis inhibition (or by inhibition of peptide bond formation) has previously been reported by Zusman, Inouye \& Pardee (1972) in strain MX74T2 $t s 52$, a thermosensitive division-defective mutant. As in strain MACr, there is a cumulative effect of the incubation time at the restrictive temperature on the level of subsequent CAP-induced division. A striking difference between the strains is that strain $t s 52$ appears to maintain the normal coupling of cell division to DNA replication.. The strain $t s 52$ and strain $\mathrm{MACr}$ mutations map at about 32 and $3 \mathrm{~min}$ respectively on the $E$. coli linkage 
Time (min) 0

Temp.

$30^{\circ} \mathrm{C}$
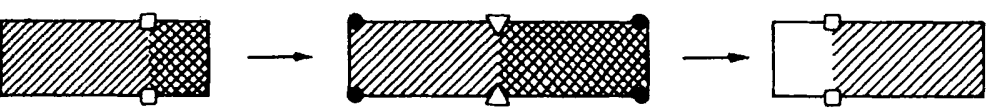

50
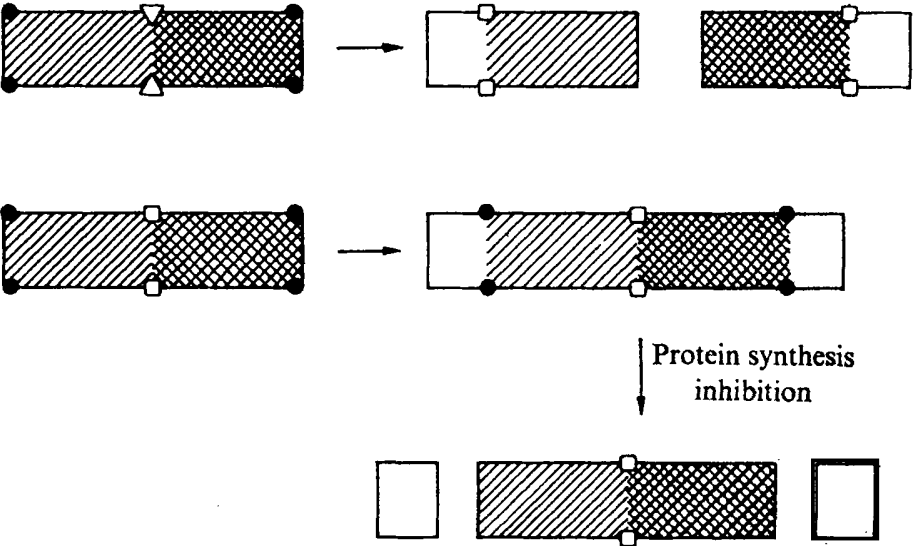

$42^{\circ} \mathrm{C}$
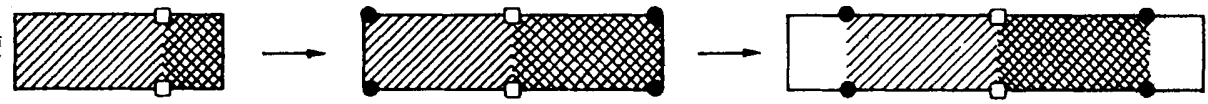

Protein synthesis
inhibition

Fig. 6. Diagram to illustrate the hypothetical changes affecting surface growth sites and a possible pattern of cell division in a cell of strain MACI grown on LB medium at $30^{\circ} \mathrm{C}(\tau$ approx. $50 \mathrm{~min})$ and incubated under the same conditions or at the restrictive temperature $\left(42{ }^{\circ} \mathrm{C}\right)$. Symbols represent different states of the surface growth sites. $O$, Sites not yet affected by the $\operatorname{div} A$ product; these sites have a primary unregulated structure with a capacity to make both peripheral wall and septum, the latter ability being elicited by protein synthesis inhibition. $\square$, Sites partially modified by the div $A$ product in a process which starts $60 \mathrm{~min}$ before division and ends $20 \mathrm{~min}$ before division; these sites are strictly engaged in cell elongation and cannot be induced to form a septum by protein synthesis inhibition. $\nabla$, Sites after completion of the div $A$ controlled process; these sites are committed to septum formation but are dependent on chromosome termination.

map. It can be inferred (Zusman et al., 1972) that control by the gene mutated in strain ts52 ends very early in the cell cycle since cells from an exponential culture growing with a generation time of $30 \mathrm{~min}$ stopped dividing in about $55 \mathrm{~min}$ when shifted to $42{ }^{\circ} \mathrm{C}$. This feature is also different in strain MACI ; $\operatorname{divA}$ control ends $20 \mathrm{~min}$ before division (Pedro et al., 1975).

Induction of cell division by protein synthesis inhibition cannot be unequivocally interpreted with the available information. On the basis of previous results (Pedro et al., 1975) and present observations, it is conceivable that the $\operatorname{div} A$ product function is to differentiate surface growth zones (potential division sites) by transforming a primary unregulated structure, with the capacity to make both peripheral wall and septum, to a secondary structure committed to septum formation. The possible sequence of changes affecting surface growth zones is illustrated in Fig. 6. It is assumed that septum formation by the surface growth zones with the primary unregulated structure can be elicited by protein synthesis inhibition, i.e. when cells are not forced to extend in length due to the absence of mass increase. This assumption is based on Pritchard's model of cell division (Pritchard, 1974) in which division occurs when synthetic capacity for wall formation exceeds that required to accommodate the increment in mass. The formation of new surface growth sites maintaining the primary structure should be necessary to induce strain MACI division by CAP or rifampicin addition. Such sites must be created by allowing cell growth to a certain size at $42{ }^{\circ} \mathrm{C}$, whether DNA replication is terminated or not. This model predicts that after incubation of strain MACr at $42{ }^{\circ} \mathrm{C}$, cells with a volume less than that critical for the formation of new surface growth sites cannot be induced to divide by CAP addition, whereas those which exceed that volume must divide and produce up to three cells if we assume that 


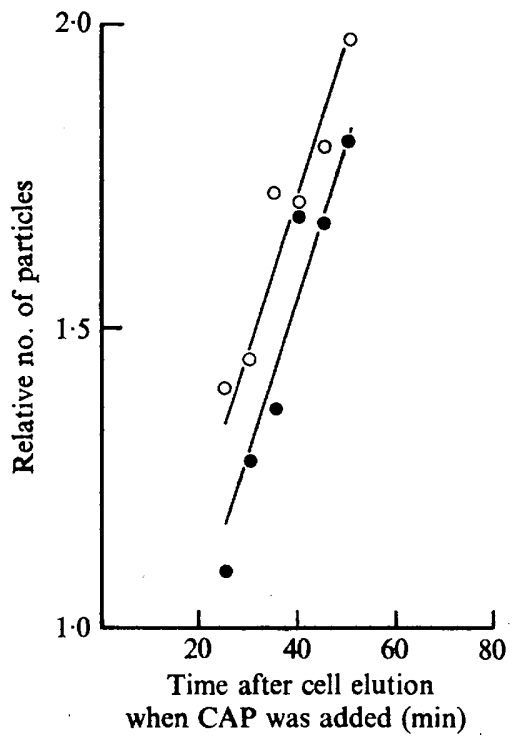

Fig. 7. Comparison of the division of strain MACI at $42^{\circ} \mathrm{C}$ in the presence of CAP with the expected cell division assuming that cells which were able to divide under these conditions made two septa. Data were from the experiment reported in Fig. 2, in which synchronous cultures were shifted to $42{ }^{\circ} \mathrm{C}$ at the time of cell elution. Theoretical values $(O)$ were calculated on the basis of cell volume distribution at the time of CAP addition; cells with a volume of less than 2 units were assumed not to divide, whereas cells of more than 2 volume units were assumed to produce up to 3 new cells. Experimental values (O) are those reported with the same symbols in Fig. $2(a)$. One volume unit is equal to the mean cell volume of the culture at the time of elution.

two new surface growth sites should be formed (Fig. 6). This prediction can be tentatively tested with the available data because cell growth of a synchronous culture of strain MACI at $42{ }^{\circ} \mathrm{C}$ was variable, producing cells of different sizes (data not shown). Experimental values for CAP-induced division after various periods at $42{ }^{\circ} \mathrm{C}$ are compared with the expected cell division according to the proposed hypothesis in Fig. 7. Both theoretical and experimental values are similar, though not equal. However, CAP partially inhibits the protein synthesis-independent division of strain MACI cells which are in the $D$ period (Pedro et al., 1975). The data in Fig. I (a) are also consistent with the suggested hypothesis that cells induced to divide by protein synthesis inhibition yield more than two daughter cells; CAP induced division after a heat shock at $42{ }^{\circ} \mathrm{C}$ more than doubled the number of particles although only 60 to $70 \%$ of the cells were able to divide in the absence of CAP. The results shown in Fig. 5 also agree with the model. When the $\operatorname{div} A$ product was inactivated one generation time after cell elution, the new potential division sites should have already lost the primary unregulated structure and should not be induced to septate by CAP addition.

We thank Professor Pritchard and Dr Donachie for reading this manuscript and for their criticisms. Technical assistance of Lola Alcain is acknowledged. This research was supported by grants from Comision Asesora de Investigación Científica y Técnica and Fundación E. Rodríguez Pascual. 


\section{REFERENCES}

Chandler, M., BiRd, R. E. \& CARo, L. (1975). The replication time of Escherichia coli 12 chromosome as a function of cell doubling time. Journal of Molecular Biology 94, 127-132.

ClaRK, D. J. (1968). The regulation of DNA replication and cell division in Escherichia coli B/r. Cold Spring Harbor Symposia on Quantitative Biology 33, 823-828.

COOPer, S. \& Helmstetter, C. E. (1968). Chromosome replication and the division cycle of Escherichia coli B/r. Journal of Molecular Biology 31, 519-540.

DonACHIE, W. D. (1968). Relationship between cell size and time of initiation of DNA replication. Nature, London 219, $1077-1079$.

Donachie, W. D., Jones, N. C. \& Teather, R. (1973). The bacterial cell cycle. Symposia of the Society for General Microbiology 23, 9-44.

Helmstetter, C. E. \& Pierucci, O. (1968). Cell division during inhibition of DNA synthesis in Escherichia coli. Journal of Bacteriology 95, 1627-1633.

Helmstetter, C. E. \& Pierucci, O. (1976). DNA synthesis during the division cycle of three substrains of Escherichia coli B/r. Journal of Molecular Biology 102, 477-486.

Pedro, M. A. De, Llamas, J. E. \& Cánovas, J. L. (1975). A timing control of cell division in Escherichia coli. Journal of General Microbiology 9x, 307-314.

Pierucci, O. \& Helmstetrer, C. E. (1969). Chromosome replication, protein synthesis and cell division in Escherichia coli. Federation Proceedings, 28, $1755-1760$.

Pritchard, R. H. (1968). Control of DNA synthesis in bacteria. Heredity 23, 472.

Pritchard, R. H. (I974). On the growth and form of bacterial cell. Philosophical Transactions of the Royal Society $267,303-336$.

Zusman, D. R., InOuYe, M. \& PARDeE, A. B. (1972). Cell division in Escherichia coli: evidence for regulation of septation by effector molecules. Journal of Molecular Biology 69, I19-136. 